\title{
Eye Lens Doses Received by Radiation Workers in Interventional Medical Procedures
}

\author{
E. Hiswara*, D. Kartikasari, H. Sofyan, N. Nuraeni and K.Y.P. Sandy \\ Center for Technology of Safety and Radiation Metrology, National Nuclear Energy Agency (BATAN), \\ Jl. Lebak Bulus Raya No. 49, Jakarta 12070, Indonesia.
}

\section{ARTICLE INFO}

\section{Article history:}

Received 9 December 2019

Received in revised form 26 August 2020

Accepted 1 September 2020

\section{Keywords:}

Medical radiation worker Eye lens doses

Interventional procedure

Dose limit

\begin{abstract}
A B S T R A C T
The International Commission on Radiological Protection (ICRP) has recently recommended that the occupational dose limit for the eye lens be reduced to $20 \mathrm{mSv}$ per year, averaged over defined periods of 5 years, with no single year exceeding $50 \mathrm{mSv}$. ICRP clearly states that the recommendations are chiefly based on epidemiological evidence that suggested the eye lens dose threshold for cataract induction revised downwards from 2-5 Gy to about $0.5 \mathrm{~Gy}$. Interventional medical workers are at greater health risk from radiation exposure to eyes as a result of the procedures they undertake than most other medical specialists. An extensive study has been carried out to measure the eye lens doses received by 373 interventional medical radiation workers in twelve large hospitals in Indonesia. Measurements were made using Thermo Scientific Harshaw thermoluminescence dosimeter (TLD) chip (size $3.2 \mathrm{~mm} \times 3.2 \mathrm{~mm} \times 0.15 \mathrm{~mm}$ ) put inside an EYE-D holder placed in the worker's temple. The procedures performed are grouped based on classification made by the UNSCEAR (United Nations Scientific Committee on the Effects of Atomic Radiation). The results showed that in general the measured data are in an agreement with some published data, even though a large range of doses was observed. The highest mean eye lens dose of $0.2378 \mathrm{mSv}$ per procedure was received by interventionists who worked in the abdominal interventions procedure. Overall, from the results of measurement, it can be concluded that most interventionists might receive eye lens dose exceeding the dose limit if the procedures are carried out on daily basis, and the abdominal interventions procedures were found to be the ones that give the highest risk to the eye lens of workers as it delivered the highest dose to this particular organ.
\end{abstract}

\section{INTRODUCTION}

The use of ionizing radiation has brought much progress in the diagnosis and treatment of diseases. One of its use is fluoroscopically-guided interventional procedures that involve small incision, puncture, and entry into a body cavity. These procedures are minimally invasive so that morbidity and mortality of patients can be reduced.

Medical doctors who specialize in performing interventional medical procedures, or interventionists, use their expertise in reading $\mathrm{X}$-rays to guide a small instrument called catheter (hollow tube with a size of a few millimeters in

*Corresponding author.

E-mail address: e.hiswara@batan.go.id

DOI: https://doi.org/10.17146/aij.2020.1012 diameter) through the blood vessels or other pathways to treat diseases percutaneously.

The interventional procedures are generally lengthy and require a large number of images. Therefore, medical staff members as well as the patients can be exposed to relatively high radiation doses from X-rays. Interventional radiologists, cardiologists, and other medical staff who stand close to patient and the X-ray source during the fluoroscopy-guided procedures are at a high risk concerning radiation-associated cataract, especially when the lens of the eye is unprotected [1].

The purpose of this paper is to report the measurement of occupational eye lens doses for various types of interventional procedures in radiology and cardiology. A separation of the different medical professions into categories was 
based on the classification used by the UNSCEAR. The risk of exceeding the annual eye lens dose limit is presented for the various categories.

\section{THEORY}

In the US, percutaneous coronary intervention (PCI) was the most-commonly performed revascularization technique with an estimated 492 000 procedures done in 2010 [2]. The aim of PCI is to dilate coronary arteries constricted by coronary artery disease, hence restoring arterial blood flow to the myocardium without open-heart surgery [3]. This procedure uses a special wire-guided catether that is inserted through constricted area into the coronary artery. A tiny balloon at the end of the catether when inflated will compress the fatty tissue obstructing the artery, thus dilating it to enhance the flow of blood into the coronay artery.

The structural heart disease procedures in the US have also been growing with more than 10000 procedures in 2013 within two years after approval, while in Europe, in the same year, it was estimated that around 38000 procedures had been performed within the first five years after approval.

The lens of the eye has long been considered as a radiosensitive tissue [4]. The accumulation of damaged or dead cells within the lens that cannot be removed naturally will lead to the development of cataract.

Based on Kleiman [5], the eye lens is an avascular tissue that receives nourishment from its surrounding aqueous and vitreous fluids. The lens is completely encased by a basement membrane termed the lens capsule. Throughout life, epithelial cells located at the periphery of the lens, in the germinative zone, divide and differentiate into mature lens fiber cells. Division slows during puberty, yet the lens continues to grow throughout life, eventually tripling in weight.

Damaged in the epithelial cell layer is believed to be the initiating event that causes lens opacification, or cataract. In a lay term, cataract is opacification of eye lens which causes obstruction of light to reach the retina.

There are three predominant forms of cataract, depending upon their anatomical location in the lens: cortical, which involving the outer cell and containing lens fibre cells; nuclear: found in the central lens fibre cells; and posterior subcapsular (PSC), which developing from aberrantly differentiating epithelial cells and resulting in opacity at the posterior pole. Radiation cataract is generally associated with PSC [6].

The damage in PSC begins when the incoming radiation exposure affects the germinative dividing cells of the anterior lens epithelium. The aberrant cells move toward the posterior pole, creating the radiation-associated PSC. Due to the avascular nature of the lens, the damaged cells cannot be removed, and their accumulation with time forms a cataract [6].

Until recently, a PSC change in the lens was described as a consistent finding after a high-dose radiation exposure. This led to the belief that cataract develops deterministically and thus requires a threshold dose and damage to multiple cells. This is also presumed by the ICRP that set the threshold for detectable opacities to be on the order of $2 \mathrm{~Gy}$ for acute exposures and $5 \mathrm{~Gy}$ for protracted exposure [7].

Some recent studies, however, have suggested that the radiosensitivity of an eye lens is higher than previously thought. Instead of 2-5 Gy, the radiation doses of around $1 \mathrm{~Gy}$ have been found to be enough to form cataract [8]. This leads the International Commission on Radiological Protection (ICRP) to propose a threshold of $0.5 \mathrm{~Gy}$ for the induction of cataract irrespective of the dose rate delivery. Responding to this decrease in threshold for cataract induction, the International Atomic Energy Agency (IAEA) then reduced the occupational dose limit for the eye lens from $150 \mathrm{mSv}$ to $20 \mathrm{mSv}$ per year [9].

New data, however, suggests that cataract may form stochastically, without a threshold dose and potentially in response to the damage of a single cell [10]. Moreover, most occupational exposures can be classified as chronic or protracted, while most of studies cited by the ICRP to support the reduction of threshold, particularly from atomic bomb survivors, were acute exposures.

A dose threshold can mathematically be calculated based on maximum likelihood from dose response models. All of the thresholds can only be found in atomic bomb survivors or Chernobyl liquidators who were subjected to acute or shortterm protracted exposures [11]. In contrast, no thresholds were calculated following occupational exposures. This suggests that there is not enough data to support the calculation of a threshold value for chronic exposures.

This reduction in threshold and dose limit, however, was met with some controversy. While the IAEA agreed with the ICRP, the IRPA (International Radiation Protection Association), based on a questionnaire circulated in 2013 to its members, questioned whether there was sufficient data to support the reduction in dose limit $[10,12]$. Even after three years since its first survey in 2013, the IRPA members still thought that such a drastic reduction in the dose limit needs due time to be implemented and applied, since it will deeply change some previously-consolidated operating procedures [13].

The high risk of developing radiation-induced cataract among interventional cardiologists was concluded in a study by Elmaraezy et al. [14]. 
They performed a systematic review and a metaanalysis of nine electronic databases and found significantly higher risk for posterior lens opacity among interventional cardiologists relative to control group, but no significant difference between both groups in cortical lens opacity and nuclear opacity.

\section{EXPERIMENTAL METHODS}

The measurements of eye lens doses were performed at the interventional radiology and catheterization laboratories in twelve hospitals in eight cities in Indonesia, namely Jakarta, Bandung, Yogyakarta, Semarang, Surabaya, Denpasar, Padang, and Banjarmasin, during the years of 2015 to 2018. A total of 373 medical staff members, consisting of 180 interventionists, 153 nurses, and 40 radiographers, were involved in this study.

Each measurement of eye lens dose was realized by using an individual chip of TLD-100 (size $3.2 \mathrm{~mm} \times 3.2 \mathrm{~mm} \times 0.15 \mathrm{~mm}$ ) from Thermo Scientific Harshaw. All TLDs were calibrated in the Secondary Standard Dosimetry Laboratory (SSDL) Jakarta. The standard deviation of the TLD batch was of the order of $5 \%$, with the overall uncertainty of $\leq 20 \%$ at the $95 \%$ confidence level.

The TLD was put into an EYE-D holder and then placed in the worker's temple as shown in Fig. 1. The EYE-D holder was developed and tested within the ORAMED (Optimization of Radiation Protection for Medical Staff) project, funded by EU-EURATOM and manufactured by Radcard Company of Poland.

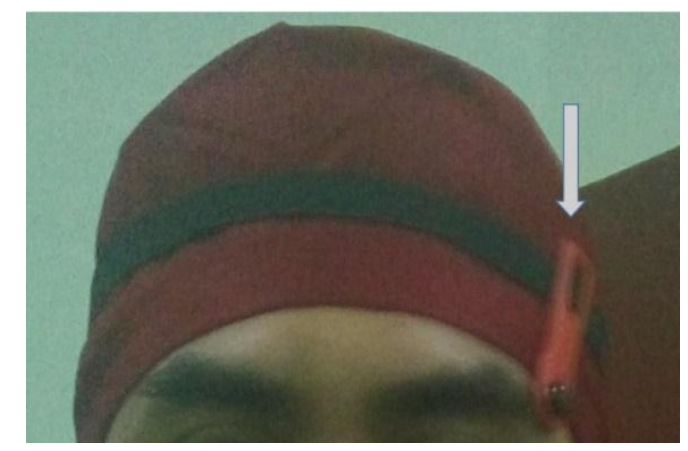

Fig. 1. The EYE-D holder used to measure eye lens dose.

\section{RESULTS AND DISCUSSION}

As can be seen in Table 1, the terms used by hospitals in describing the interventional procedures they conducted are varied. To simplify them, those terms are grouped based on the classification used by the UNSCEAR in its questionnaire for global survey of medical radiation exposure [15], with a slight modification. The grouping of procedures, based on a modified UNSCEAR's classification, is shown in Table 1, whereas the full terms of the abbreviations used are listed in Table 2.

Table 1. Grouping of procedures based on a modified UNSCEAR classification.

\begin{tabular}{|c|c|}
\hline $\begin{array}{c}\text { Term of procedures used by } \\
\text { hospitals }\end{array}$ & $\begin{array}{c}\text { Modified UNSCEAR } \\
\text { classification }\end{array}$ \\
\hline $\begin{array}{l}\text { DSA cerebral, DSA brain, DSA } \\
\text { neuro, coiling }\end{array}$ & $\begin{array}{l}\text { Head (cerebral } \\
\text { interventions) }\end{array}$ \\
\hline $\begin{array}{l}\text { PTCA, PA, angio+elective } \\
\text { PTCA, angio, } \\
\text { PAC and PTCA, CA }\end{array}$ & PTCA \\
\hline EP study, pacemaker & Chest (pacemaker) \\
\hline $\begin{array}{l}\text { Stenting, LAA, catheterization, } \\
\text { cholangiography, PA, PAC, } \\
\text { ablation, cathscan, ASO, BPV, } \\
\text { cardiac, PDA closure, } \\
\text { pericardionesis, DX-RL, } \\
\text { PTMC, TFCA, LL diagnosis, } \\
\text { DCA adhoc, AVO, DCA, } \\
\text { pericardial synthesis }\end{array}$ & $\begin{array}{l}\text { Thoracic interventions } \\
\text { (other than PCI) }\end{array}$ \\
\hline $\begin{array}{l}\text { Urethrocystography, } \\
\text { cystography, MCU, bipolar } \\
\text { urethrocystography, PTBD }\end{array}$ & $\begin{array}{l}\text { Abdomen (biliary and } \\
\text { urinary interventions) }\end{array}$ \\
\hline $\begin{array}{l}\text { Fistulography, Upper } \\
\text { gastrointestinal, OMD } \\
\text { aesophagus, distal colography, } \\
\text { colostomi proximal }\end{array}$ & Abdominal interventions \\
\hline HSG & Pelvic interventions \\
\hline Vascular peripheral, APG & Limb interventions \\
\hline $\begin{array}{l}\text { Embolization angiofibroma, } \\
\text { embolization TAE, TACE }\end{array}$ & Embolization \\
\hline $\begin{array}{l}\text { PCI, PCI stent, CAG PCI, early } \\
\text { PCI, PAC standby PCI, PCI } \\
\text { RCA, primary PCI, elective } \\
\text { PCI, PCI venticulography, } \\
\text { arteriography }\end{array}$ & PCI \\
\hline
\end{tabular}

Table 2. Full terms of abbreviations.

\begin{tabular}{ll}
\hline Abbreviation & \multicolumn{1}{c}{ Full term } \\
\hline APG & air plethysmography \\
ASO & arterial switch operation \\
AVO & aortic valve opening \\
BPV & balloon pulmonary valvulopasty \\
CA & coronary angioplasty \\
CAG & coronary angiography \\
DCA & directional coronary atherectomy \\
DX-RL & deep X-ray lithography \\
EP & electrophysiology \\
HSG & hysterosalpingography \\
LAA & left atrial appendage \\
LL & local lysis \\
MCU & micturating cysto-urethrogram \\
OMD & oromotor dysfunction \\
PA & pulmonary artery (stenosis) \\
PAC & premature atrial contraction \\
PCI & percutaneous coronary intervention \\
PDA & patent ductus arteriosus \\
PTA & percutaneous transluminal angioplasty \\
PTBD & percutaneous transhepatic biliary drainage \\
PTCA & percutaneous transluminal coronary \\
PTMC & angioplasty \\
RHC & percutaneous transvenous mitral \\
TACE & commissurotomy \\
TAE & right heart catheterization \\
TFCA & transarterial chemoembolization \\
& transcatheter arterial embolization \\
& thin fibrous cap atheroma \\
\hline
\end{tabular}


Table 3 shows the number of measurements for each procedure with its respective mean fluoro time. As can be seen, thoracic interventions (other than PCI) and PCI are the most-performed interventional procedures during the measurement period of 2015-2018, and most probably for the country. In Poland, PCI procedure (113 928 cases) was the second most performed procedure after CAG (208 842 cases) in 2012 [3], whereas in Thailand the average number of PCI and CAG cases per year was 700-800 and 1300, respectively, during a study started in December 2015 and continued for three years [16].

Table 3. Number of measurements and fluoro time.

\begin{tabular}{lcc}
\hline \multicolumn{1}{c}{ Procedure } & $\begin{array}{c}\text { Number of } \\
\text { measurements }\end{array}$ & $\begin{array}{c}\text { Mean fluoro } \\
\text { time (range), } \\
\text { min }\end{array}$ \\
\hline $\begin{array}{l}\text { Head (cerebral } \\
\text { interventions) }\end{array}$ & 18 & $8.13(1.38-17.93)$ \\
PTCA & 27 & $19.31(1.32-$ \\
Chest (pacemaker) & 3 & $118.4)$ \\
$\begin{array}{l}\text { Thoracic interventions } \\
\text { (other than PCI) }\end{array}$ & 50 & $9.59(3.39-9.20)$ \\
$\begin{array}{l}\text { Abdomen (biliary and } \\
\text { urinary interventions) }\end{array}$ & 7 & $1.32(0.15-2.26)$ \\
$\begin{array}{l}\text { Abdominal } \\
\text { interventions }\end{array}$ & 6 & $4.12(1.30-8.36)$ \\
Pelvic interventions & & $3.11-96.29)$ \\
Limb interventions & 1 & $16.97(0.21-$ \\
Embolization & 3 & $50.29)$ \\
PCI & 5 & $21.74(4.05-$ \\
& & $59.24)$ \\
\hline
\end{tabular}

The fluoro time used as given in Table 3 shows that its range for each procedure is quite wide. This is understandable since each procedure is actually a group of several procedures that have slightly similar techniques, and most of the procedures were actually performed by residents but supervised by senior interventionists.

The result of measurements is presented in Table 4. It should be noted that the numbers of measurements were not the same as numbers of workers, as one worker can in many cases be involved in more than one procedures. Therefore, the numbers of measured workers mostly were more than the numbers of individual workers.

As can be seen from Table 4, most data were obtained from interventionists who performed thoracic intervention with the mean eye lens dose received was $0.0794 \mathrm{mSv}$. However, the highest mean eye lens dose of $0.2378 \mathrm{mSv}$ was received by interventionists who performed abdominal intervention. This might due to the position of their abdomen that is in the same height with the patient's body so that this organ received more scattered dose from the patients compared with other organs.

Nevertheless, seven data can be regarded as not reliable since they gathered from only one measurement. This could not be avoided since the data were gathered on the spot, and the procedures were rarely performed.

Table 4. Mean eye lens dose for various interventional procedures and type of workers.

\begin{tabular}{|c|c|c|c|}
\hline Procedure & Type of worker & $\begin{array}{c}\text { Number of } \\
\text { measurements }\end{array}$ & $\begin{array}{c}\text { Mean eye lens dose (range), } \\
\mathrm{Hp}(3) \text {, in } \mathrm{mSv} \\
\end{array}$ \\
\hline \multirow[t]{3}{*}{ Head (cerebral interventions) } & Interventionist & 21 & $0.1617(0.0130-0.6408)$ \\
\hline & Nurse & 31 & $0.1608(0.0307-0.6330)$ \\
\hline & Radiographer & 8 & $0.0871(0.0679-0.1064)$ \\
\hline \multirow[t]{2}{*}{ PTCA } & Interventionist & 19 & $0.0410(0.0081-0.0701)$ \\
\hline & Nurse & 17 & $0.0657(0.0260-0.1263)$ \\
\hline \multirow[t]{3}{*}{ Chest (pacemaker) } & Interventionist & 2 & $0.0212(0.0078-0.0347)$ \\
\hline & Nurse & 6 & $0.0612(0.0339-0.0886)$ \\
\hline & Radiographer & 1 & 0.0733 \\
\hline \multirow[t]{3}{*}{ Thoracic interventions (other than PCI) } & Interventionist & 67 & $0.0794(0.0140-0.5625)$ \\
\hline & Nurse & 66 & $0.0643(0.0090-0.2269)$ \\
\hline & Radiographer & 9 & $0.0589(0.0346-0.1176)$ \\
\hline \multirow[t]{2}{*}{ Abdomen (biliary and urinary interventions) } & Interventionist & 11 & $0.1391(0.0470-0.2606)$ \\
\hline & Nurse & 1 & 0.0541 \\
\hline Abdominal interventions & Interventionist & 10 & $0.2378(0.0380-0.6845)$ \\
\hline \multirow[t]{2}{*}{ Pelvic interventions } & Interventonalist & 1 & 0.0615 \\
\hline & Radiographer & 1 & 0.0572 \\
\hline \multirow[t]{3}{*}{ Limb interventions } & Interventionist & 4 & $0.1200(0.1073-0.1327)$ \\
\hline & Nurse & 1 & 0.0554 \\
\hline & Radiographer & 1 & 0.0733 \\
\hline \multirow[t]{3}{*}{ Embolization } & Interventionist & 10 & $0.1187(0.0276-0.1477)$ \\
\hline & Nurse & 1 & 0.0190 \\
\hline & Radiographer & 3 & $0.1201(0.0572-0.2277)$ \\
\hline \multirow[t]{3}{*}{ PCI } & Interventionist & 35 & $0.0818(0.0329-0.1555)$ \\
\hline & Nurse & 31 & $0.0759(0.0102-0.2322)$ \\
\hline & Radiographer & 17 & $0.0974(0.0296-0.2683)$ \\
\hline
\end{tabular}


With a dose limit for eye lens of $20 \mathrm{mSv} / \mathrm{y}$, and assuming that each worker carries out one procedure per day, working 5 days per week and 50 weeks per year, then the maximum permissible eye lens dose received by each worker would be 0.08 $\mathrm{mSv}$ per procedure. Table 5 shows that six procedures might give eye lens doses exceeding the dose limit of $20 \mathrm{mSv} / \mathrm{y}$ if they are carried out on a daily basis, with interventionist being the most exposed worker in those six procedures.

Table 5 also shows the recommended number of procedure carried out in a year. This was calculated by assuming that each worker performs only one type of procedure per day. It can be seen that the recommended number of procedures ranges from 84 for an interventionist performing abdominal interventions to 1052 for a nurse performing embolization.

Theoretically, the interventionists are expected to always receive the highest radiation dose because they stand frontmost against the position of the head of the lying-down patient compared to the position of the nurse and radiographer. This position can be considered to be the closest to the primary beam of the X-ray used.

The high risk to the interventionist was confirmed by an assessment of the occupational eye lens dose based on clinical measurements. Omar, et.al. [17] found that the risk of exceeding the annual eye lens dose limit is of concern for staff members that work regularly beside the patient, i.e., radiologists/cardiologists.

In several procedures, however, it was seen that it was not the interventionist but the nurse who received the highest eye lens dose. This implies that sometimes it is the position of the nurse that is probably closer to the X-ray beam, rather than the interventionist's position, when the former helps the latter in a short distance.

Another possible cause is that the amount of scattered radiation received by nurses or radiographers is more than that received by the interventionist. Therefore, the radiation dose received by the nurse or radiographer also becomes greater than that received by the interventionist.

In Riyadh, staff member eye doses in a large medical center were measured by Al-Haj et al. [18]. The measurement results from 34 staff members showed that the doses per cardiology procedure were $0.003 \mathrm{mSv}, 0.005 \mathrm{mSv}$ and $0.018 \mathrm{mSv}$ for technologist, nurse, and cardiologist, respectively.

The eye lens doses were also measured by using phantom to simulate cardiologist and TLD as dosimeter [19]. The doses at the left eye, which was also the position in this study, were found to be in the range of $0.15-0.63 \mathrm{mSv}$.

Table 5. Projected dose in a year and recommended number of procedure carried out in a year.

\begin{tabular}{|c|c|c|c|c|}
\hline Procedure & Type of worker & $\begin{array}{c}\text { Mean eye lens dose } \\
(\mathrm{mSv})\end{array}$ & $\begin{array}{c}\text { Projected dose received in } \\
\text { a year }(\mathrm{mSv})\end{array}$ & $\begin{array}{c}\text { Recommended number } \\
\text { of procedure carried } \\
\text { out in a year }\end{array}$ \\
\hline Head (cerebral interventions) & $\begin{array}{l}\text { Interventionist } \\
\text { Nurse }\end{array}$ & $\begin{array}{l}0.1617 \\
0.1608 \\
0.0871\end{array}$ & $\begin{array}{c}40.42 \\
40.2 \\
21.77\end{array}$ & $\begin{array}{l}123 \\
124 \\
229\end{array}$ \\
\hline PTCA & & $\begin{array}{l}0.0410 \\
0.0657\end{array}$ & $\begin{array}{l}10.25 \\
16.42\end{array}$ & $\begin{array}{l}487 \\
304\end{array}$ \\
\hline Chest (pacemaker) & $\begin{array}{l}\text { Nurse } \\
\text { Radiographer }\end{array}$ & $\begin{array}{l}0.0212 \\
0.0612 \\
0.0733\end{array}$ & $\begin{array}{c}5.3 \\
15.3 \\
18.32\end{array}$ & $\begin{array}{l}943 \\
326 \\
272\end{array}$ \\
\hline $\begin{array}{l}\text { Thoracic interventions (other } \\
\text { than PCI) }\end{array}$ & $\begin{array}{l}\text { Interventionist } \\
\text { Nurse } \\
\text { Interventionist }\end{array}$ & $\begin{array}{l}0.0794 \\
0.0643 \\
0.0589\end{array}$ & $\begin{array}{l}19.85 \\
16.07 \\
14.72\end{array}$ & $\begin{array}{l}251 \\
311 \\
339\end{array}$ \\
\hline $\begin{array}{l}\text { Abdomen (biliary and urinary } \\
\text { interventions) }\end{array}$ & $\begin{array}{l}\text { Interventionist } \\
\text { Nurse }\end{array}$ & $\begin{array}{l}0.1391 \\
0.0541\end{array}$ & $\begin{array}{l}34.77 \\
13.52\end{array}$ & $\begin{array}{l}143 \\
369\end{array}$ \\
\hline Abdominal interventions & Interventionist & 0.2378 & 59.45 & 84 \\
\hline Pelvic interventions & $\begin{array}{l}\text { Interventionist } \\
\text { Radiographer }\end{array}$ & $\begin{array}{l}0.0615 \\
0.0572\end{array}$ & $\begin{array}{l}15.37 \\
14.3\end{array}$ & $\begin{array}{l}325 \\
349\end{array}$ \\
\hline Limb interventions & $\begin{array}{l}\text { Interventionist } \\
\text { Nurse } \\
\text { Radiographer }\end{array}$ & $\begin{array}{l}0.1200 \\
0.0554 \\
0.0733\end{array}$ & $\begin{array}{c}30 \\
13.85 \\
18.32\end{array}$ & $\begin{array}{l}166 \\
361 \\
272\end{array}$ \\
\hline Embolization & $\begin{array}{l}\text { Interventionist } \\
\text { Nurse } \\
\text { Radiographer }\end{array}$ & $\begin{array}{l}0.1187 \\
0.0190 \\
0.1201\end{array}$ & $\begin{array}{c}29.67 \\
4.75 \\
30.02\end{array}$ & $\begin{array}{c}168 \\
1052 \\
166\end{array}$ \\
\hline PCI & $\begin{array}{l}\text { Interventionist } \\
\text { Nurse } \\
\text { Radiographer }\end{array}$ & $\begin{array}{l}0.0818 \\
0.0759 \\
0.0974\end{array}$ & $\begin{array}{l}20.45 \\
18.97 \\
24.35\end{array}$ & $\begin{array}{l}244 \\
263 \\
205\end{array}$ \\
\hline
\end{tabular}


Moreover, a study conducted by Principi et al. [20] using Monte Carlo simulations showed that left eye exposure is generally higher than the right eye when the operator stands on the right side of the patient. This operator position was the case for the most, if not all, interventional procedures conducted in Indonesia.

The doses reported in this study are generally within the range of some previously published data. The occurrence of some variation is understandable since the doses measured in a medical setting are dependent upon many of factors, including the equipment used, the operational procedures of the radiologist and interventionist, and the protective equipment worn [21]. From the radiation protection point of view, all hospitals utilize the ceilingsuspended screen to reduce the occupational exposure. However, the large range of eye lens doses received by medical workers, as shown in Table 4, could give rise to the conjecture that the screen is not always used appropriately. Moreover, because of practicality reasons, fewer than $10 \%$ of workers wear lead eyeglasses.

\section{CONCLUSION}

The doses reported in this study are generally within the range of some published data. However, a large range of eye lens doses receive were observed. Most interventionists might receive eye lens dose exceeding the dose limit if the procedures are carried out on daily basis, and abdominal intervention procedures were found to be the one that give the highest risk to the eye lens of workers as it delivered the highest dose to this particular organ.

\section{ACKNOWLEDGMENT}

The work was funded by the 2015-2018 financial year research budget of the Indonesian government through the Center of Radiation Safety Technology and Metrology, the National Nuclear Energy Agency (BATAN). The authors wish to thank the management and staff of the twelve hospitals in eight cities in Indonesia for granting permission to carry out the measurements in their respective hospital. The authors also acknowledge the help from Helfi Yuliati for preparing and reading the TLDs.

\section{REFERENCES}

1. E.P. Efstathopoulos, Imaging Med. 8 (2016) 1.
2. D.P. Faxon and D.O. Williams, Circulation 133 (2016) 2697.

3. A. Szumska, R. Kopeć and M. Budzanowski, Radiat. Meas. 84 (2016) 34

4. N. Hamada, Int. J. Radiat. Biol. 93 (2017) 1024.

5. N.J. Kleiman, Radiation cataract, Proceedings of the First ICRP Symposium on the International System of Radiological Protection, Ann. ICRP 41(3-4) (2012) 80.

6. K.F. Seals, E.W. Lee, C.H. Cagnon et.al., Cardiovasc. Intervent. Radiol. 39 (2016) 151.

7. R.E. Shore, Mutat. Res-Rev. Mutat. 770 (2016) 231.

8. E.A. Ainsbury, S. Barnard, S. Bright et.al, Mutat. Res-Rev. Mutat. 770 (2016) 238.

9. Anonymous, Radiation Protection and Safety of Radiation Sources: International Basic Safety Standards, Safety Standards Series No. GSR Part 3. IAEA, Vienna (2014).

10. J. Broughton, M.C. Cantone, M. Ginjaume et.al., Radiat. Prot. Dosim. 164 (2015) 70.

11. C. Thome, D.B. Chambers, A.M. Hooker et.al., Health Phys. 114 (2018) 328.

12. J. Broughton, M.C. Cantone, M. Ginjaume et.al., Ann. ICRP 44 (2015) 138.

13. M.C. Cantone, M. Ginjaume, S. Miljanic et.al., J. Radiol. Prot. 37 (2017) 527.

14. A. Elmaraezy, M.E. Morra, A.T. Mohammed et.al., Catheter Cardiovasc. Interv. 1 (2017) 1.

15. Anonymous, UNSCEAR's Global Survey of Radiation Exposure: Medical Exposure. http://www.survey.unscear.org/lib/exe/fetch.ph p/unscear_medical_exposure_survey_manual_v 2.pdf. Retrieved in March (2019).

16. A. Krisnachinda, S. Srimahachota and K. Matsubara, Radiol. Phys. Technol. 10 (2017) 142.

17. A.Omar, N. Kadesjö, C. Palmgren et.al, J. Radiol. Prot. 37 (2017) 145.

18. A. Al-Haj, A. Lobriguito and I. Al-Gain, Radiat. Prot. Dosim. 165(4) (2015) 294.

19. S. Yokoyama, S. Suzuki, H. Toyama et.al., Radiat. Prot. Dosim. 173 (2017) 218.

20. S. Principi, J. Farah, P. Ferrari et.al., Phys. Med. 32 (2016) 1111.

21. E.A. Ainsbury, S. Bouffer, M. Cocker et.al., J. Radiol. Prot. 34 (2014) 15. 